\title{
FROM CONCEPTS TO PRACTICAL TOOLS OF SUPPORT: DEVELOPMENT OF THE CREATIVE SECTOR IN WARSAW
}

\author{
Sylwia Dudek-MańKowsKa, Magdalena Fuhrmann \\ Institute of Socio-Economic Geography and Spatial Management, University of Warsaw, Poland
}

Manuscript received: December 15, 2011

Revised version:November 20, 2012

\begin{abstract}
Dudek-MańKowsKa S., Fuhrmann M., 2012. From concepts to practical tools of support: Development of the creative sector in Warsaw. Quaestiones Geographicae 31(4), Bogucki Wydawnictwo Naukowe, Poznań, pp. 125-132. 1 table, 2 figs. DOI 10.2478/v10117-012-0041-5, ISSN 0137-477X.

AвSTRACT. Warsaw is a metropolitan city with great creative potential. All the national media as well as editorial offices of most newspapers and periodicals of national circulation are located here. Mass media, educational institutions, and cultural institutions along with a community of educated and affluent people make Warsaw a leading cultural centre both in terms of potential in creative activities and as a market for products coming from the creative sector. Although the creative sector seems to be treated as an important part of the economic base of Warsaw's development, creative potential located in the city seems to be underused. The goal of this paper is to present the support of city authorities for the development of the creative sector in Warsaw. The evaluation of problems and bottlenecks articulated by representatives of the creative sector will be confronted with the opinions of representatives of the City Hall.
\end{abstract}

KEY WORDS: creative sector, creativity, Warsaw

Sylwia Dudek-Mańkowska, Magdalena Fuhrmann, Institute of Socio-Economic Geography and Spatial Management, University of Warsaw, Krakowskie Przedmieście 30, 00-927 Warsaw, Poland; e-mail: s.mankowska@uw.edu.pl, mfuhrmann@uw.edu.pl

\section{Introduction}

Creativity was perceived as an important factor in the local and regional development already in the 1980s. Many authors claimed that there were strong interactions between creativity, innovation and the economy. The core of the creative sector is generating new ideas, so creativity is perceived as a condition imperative for innovation; and innovation is defined as ways to realise those concepts. Some authors also indicate that the development of creativity and innovation in cities is conducive to the establishment of new businesses and jobs. Despite the fact that there is a rich body of literature concerning the subject of creativity and its effects on entrepreneurship and the economic development of cities, there is no single universal definition of creativity and the creative sector. It is also hard to unequivocally define the origin of the concept of the creative sector. In 1983 Törnqvist coined the term creative milieu. He argued that it involved such key features as information which is exchanged and inter-traded, knowledge accumulated in time, and competence in certain activities. Putting these three features together allows the development 
of another one - creativity, defined as the ability to create new forms and values (Stryjakiewicz et al. 2009). The concept of creative industries is thought to have emerged in Australia in the early 1990s. In 1994, the Keating Government released its cultural Creative Nation policy to describe the challenges of innovation in information technologies. It was a cultural and an economic policy (Hong Kong .... 2006). The term 'creative industries' became popular in Great Britain in the late 1990s when the first Blair administration set up its Creative Industries Task Force to outline the promotion of creative industries. The Department for Culture, Media and Sport (DCMS) was established to define, among others, the activity of entities constituting the creative sector in the country. In the meantime many other countries launched studies of the functioning of the creative industries.

However, it needs to be pointed out that Florida's (2005) work had an important impact on the course of discussion about the meaning of creativity in the development of cities. The task of local authorities should be to raise the quality of life and education, i.e. provide citizens with access to various services, as well as with possibilities of living in an open, diversified city, tolerant and full of attractions. More and more often authors repeat after Florida that cities which want to develop have to prevent loss of their creative force, implement measures to support creative individuals and use their skills to raise the city's settlement, investment and tourist attractiveness. Nowadays the creative sector has become a focus of research of different scientific domains which analyse its functioning in social and economic structures. Analyses also cover the approach of local authorities to the development of the creative sector, as well as forms of its support.

Warsaw is referred to as a city of great creative potential. All the national media, numerous scientific institutions and universities, as well as important cultural establishments are located there. University graduates, highly-qualified specialists in different areas, persons with 'niche' professions and their activity constitute a potential which largely determines the directions of Warsaw's social and economic development. The scope of activity of companies operating in Warsaw is broad. It is very characteristic of the econ- omy of a metropolitan city. The city authorities have also started to appreciate the significance of the creative sector. The aim of this study is to present the support of the city authorities for the development of the creative city in Warsaw. The capital has been implementing an active policy to support entrepreneurship for more than a decade now. Various programmes are addressed to potential entrepreneurs who are planning to move their business here or establish a new one, but the idea of support of creative industries is rather new in the city. The article is based on the results of a study commissioned by the Warsaw City Hall in 2010 and our own research continued in 2011.

There is no universal definition of the creative sector. Areas constituting this sector are versatile, which makes it difficult to carry out comparative studies. It was decided to adopt the definition proposed by the British Department for Culture, Media and Sport (DCMS) in its studies. The creative sectors were defined as those based on individual creativity, skill and talent. DCMS includes the following in the creative sector: advertising, architecture, art and antiques markets, computer games, crafts, design, designer fashion, film and video, music, performing arts, publications, software, and television and radio.

\section{The creative sector in Warsaw}

The first step of our research was to estimate the size of the creative sector in Warsaw (Table 1). It was a big problem defining the number of entities operating in it. The size and quality of the creative sector are directly related to Warsaw's economic development base and the scope of its exogenous functions. First, economic entities assigned to NACE sections which are characteristic of creative activity were selected from the REGON statistical business register. Entities were then selected for further research as a result of a preliminary verification of the given business. The next phase involved a questionnaire survey covering all the selected entities. The survey concerned their activity: date of establishment, primary activity, size of the market where they sell their products/services, corporate relationships, etc. In the course of a questionnaire survey 
Table 1. Estimating the size of the creative industry in Warsaw.

\begin{tabular}{|c|c|c|c|c|}
\hline Stage & Selection & Criterion & $\begin{array}{c}\text { Number } \\
\text { of entities }\end{array}$ & $\begin{array}{c}\text { Share } \\
\%\end{array}$ \\
\hline Stage 1 & Number of business entities in Warsaw & & 324,282 & 100.00 \\
\hline Stage 2 & $\begin{array}{c}\text { Selection of entities from REGON data- } \\
\text { base by section }\end{array}$ & NACE* classification & 35,716 & 11.01 \\
\hline Stage 3 & $\begin{array}{c}\text { Selection of entities for questionnaire } \\
\text { survey }\end{array}$ & $\begin{array}{c}\text { Size, international ties, availability of } \\
\text { address and telephone data }\end{array}$ & 15,717 & 4.85 \\
\hline Stage 4 & $\begin{array}{c}\text { Entities which participated in telephone } \\
\text { survey }\end{array}$ & Interview carried out & 3,114 & 0.96 \\
\hline Stage 5 & $\begin{array}{c}\text { Excluding non-creative entities, deter- } \\
\text { mining error in estimation of size of } \\
\text { creative sector }\end{array}$ & $\begin{array}{c}\text { Declaration of the kind of business } \\
\text { activity actually carried out }\end{array}$ & 2,543 & 0.78 \\
\hline Stage 6 & $\begin{array}{c}\text { Estimating size of creative industry } \\
\text { after accommodation of error }\end{array}$ & Declaration of business activity & 23,110 & 7.12 \\
\hline
\end{tabular}

* Section G: 47.78.Z; Section J: 58.11.Z, 58.13.Z, 58.14.Z, 58.19.Z, 58.21.Z, 59.11.Z, 59.13.Z, 59.14.Z, 59,20.Z, 60.10.Z, 60.20.Z; Section M: 71.11.Z, 73.11.Z, 73.12.A, 73.12.B, 73.12.C, 73.12.D, 74.10.Z, 74.20.Z; Section R: 90.01.Z, 90.02.Z, 90.03.Z, 90.04.Z, 91.01.A, 91.01..B, 91.02.Z, 91.01.Z Source: Dudek-Mańkowska et al. (2011).

it turned out that the REGON register contained a lot of out-dated, erroneous, or totally false data. As a result, full interviews were carried out with selected entities. By referring the number of creative entities identified in the study to the total number of economic entities in the capital, it was estimated that there were about 23,000 creative entities in Warsaw (Dudek-Mańkowska et al. 2011).

Entities in Warsaw represent all areas considered creative by DCMS (Fig. 1). In their structure there is a clear predominance of such areas as advertising, architecture, traditional publishing, designer fashion, and design. This fact probably means that Warsaw specialises in those fields, for several reasons. The most important one is a phenomenon commonly referred to as the agglomeration benefit, which involves a big outlet market in the form of citizens and businesses of a metropolitan area. The Warsaw market has a highly internationalised ownership structure and a relatively large number of big companies. It is determined by the city's metropolitan nature and the attractiveness of its market to foreign investors. A small representation of art and electronic publishing market is caused by relatively limited development of these areas. Crafts, which have a similar share in the creative industry as elec-

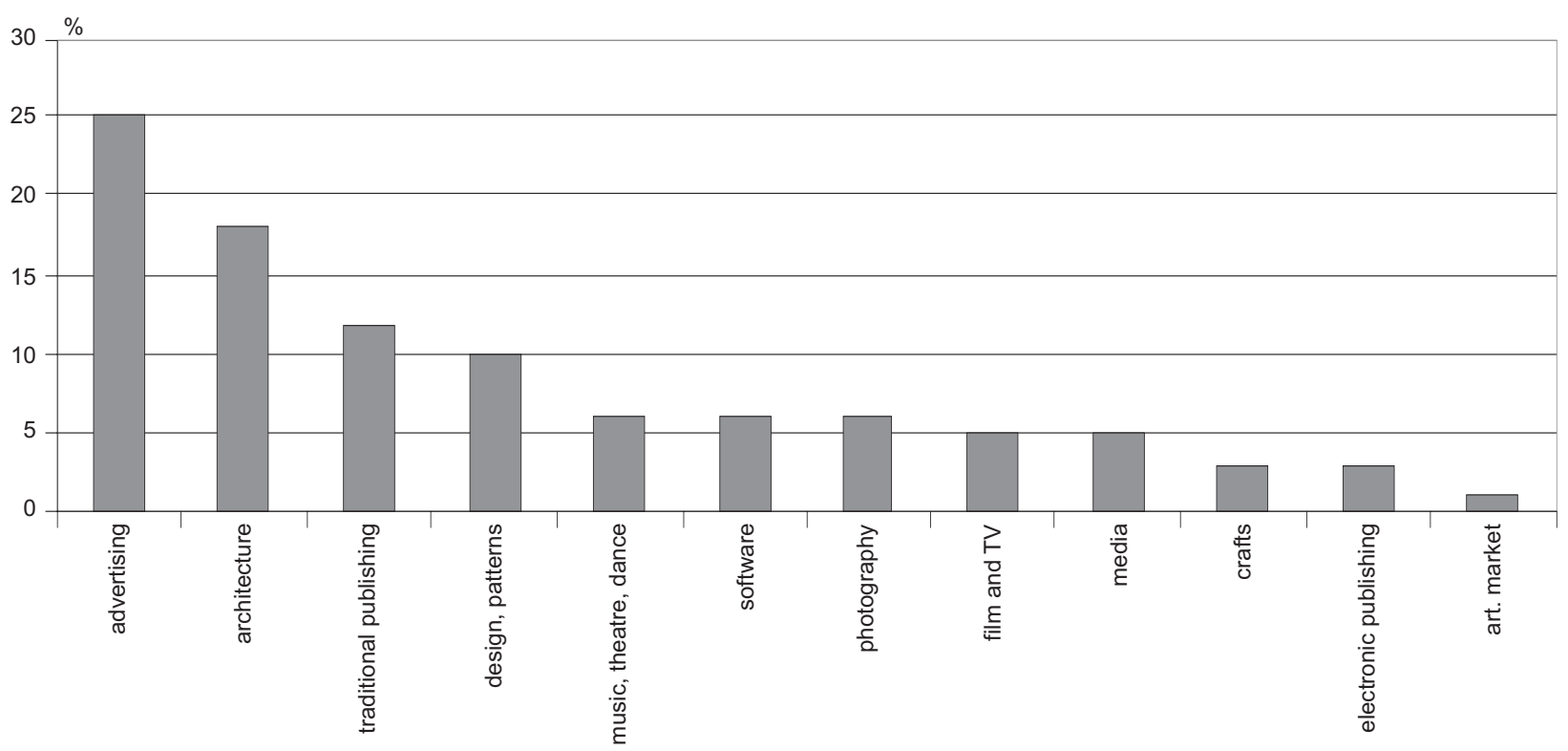

Fig. 1. The structure of creative entities in Warsaw by area of activity in 2008. Source: own study. 
tronic publishing, are likely to become more popular, because of a better quality of hand-made products.

In view of the research results, it is possible to draw a picture of a typical creative business: usually managed by a private and Polish owner (less often a company), commonly having the form of a micro-business, and established after 2004. The small size is an asset allowing flexible adjustments to the changing market.

The analysis also covered changes in the concentration of the creative sector over the period 1990 to 2010. The biggest growth in the number of creative companies occurred in 2006 and 2007. The establishment of a creative business is strictly related to the level of inhabitants' wealth and the dynamics of economic development. At the beginning of 1990s creative businesses were mainly set up in the central city districts, like Śródmieście, Mokotów and Wola. Between 1990 and 2008 the largest growth of entities in the creative sector was recorded in the Mokotów and Śródmieście districts. Śródmieście is the high-

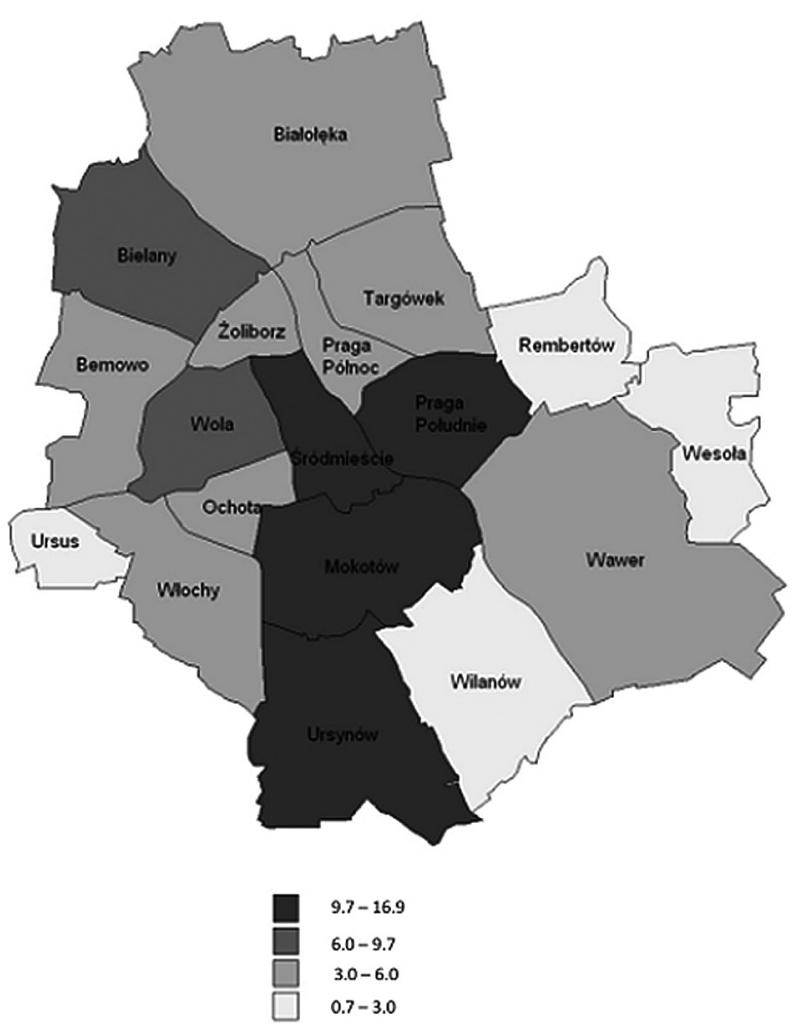

Fig. 2. Share of enterprises of the creative sector in the total number of enterprises in Warsaw by district, 2008. Source: Dudek-Mańkowska et al. (2011). density city centre with direct access to sources of information, e.g. offices of administration and culture. Mokotów has active local communities. Żoliborz is modern and has the largest percentage of persons with higher education. Low prices and the climate of the pre-war city are what make Praga Północ an attractive place for investors, artists and tourists.

\section{Assessment of Warsaw as the location for a business in the creative sector}

In order to determine conditions for the development of the creative sector in Warsaw, an in-depth quality study was performed involving companies from this sector and NGOs carrying out creative activities or representing creative milieus. The study made it possible to assess the attractiveness and competitiveness of Warsaw as a place for conducting a creative activity, to identify locations particularly attractive to the creative sector, and to indicate expectations of the sector concerning the policy of authorities. After a diagnosis of the operation of the sector in Warsaw, an analysis was made of the policy of development support offered by the local authorities.

It must be pointed out that business entities participating in the study had serious problems with identifying what a creative sector was. Moreover, they were not aware of the fact that they themselves were part of this sector. This proves that the concept of creativity is not well known and the term 'creative sector' is unclear. The functioning of the creative sector in Warsaw is assessed in many different ways by its representatives. The majority thinks that the sector's potential is great, but still remains unused. Despite the fact that the Warsaw market is highly saturated with entities of the creative sector and the products it offers, it is hard to consider the development of this offer in Warsaw as an arranged and planned process. As a result, market saturation with creative-sector companies has no impact on the city's image, while creative products are not its characteristic factors.

Representatives of the creative sector have different opinions of Warsaw's attractiveness for their activity, but positive opinions are in the ma- 
jority. The main factors of Warsaw's attractiveness include:

- location of the city, which offers good communication possibilities with other big cities in Poland where customers are based,

- presence of the most important trading, marketing and tourist companies in the country,

- versatility of companies on the market,

- presence of scientific institutions.

The high versatility and number of companies on the market enables cooperation with other entities on the one hand, and can provide a large potential outlet market on the other. There are a lot of creative spaces in the city. Areas particularly attractive for new large investments (software production, media houses, TV production) are in peripheral districts, such as Wawer, Wesoła, Rembertów, and Włochy. Praga is said to be a place with best conditions for the cultural sector. It appears that there are still unnoticed areas which could be developed by setting up a creative activity. They include:

- the Kabaty and Kabacki Forest areas (Ursynów district), which are unused and interesting spaces,

- Żoliborz - a district with a rich history and well-developed social capital, and

- Powiśle (Śródmieście district) with a lot of bookstores, cafés hosting cultural events, discussion clubs, scientific and musical facilities, the University of Warsaw Library and the Copernicus Science Centre. The respondents were of the opinion that a concentration of entities was important only for selected creative industries (culture, art, film), while for others such a location did not play any important role.

Warsaw's competitiveness is assessed rather negatively. According to representatives of NGOs operating in the creative sector, the capital has a great potential which could be crucial for the city if used properly. Important factors for Warsaw's competitiveness involve:

- the policy of urban authorities, including flat management, but also the development and promotion of creative products;

- costs of carrying out business activity;

- the city image, including the image built by creative products.

There were other Polish cities also judged as very attractive for the creative sector in the re- spondents' view. Those were Wrocław because of its social environment and unique architecture, and Cracow with its cultural image and great involvement of the local authorities. Additionally the respondents mentioned cities which had scientific and technological parks, as well as urban programmes supporting the creative industries (Gdynia, Wrocław, Poznań, Cracow and Gliwice).

\section{Forms of support for the creative- sector development offered by local authorities}

In order to determine the scope and forms of support for the creative sector in Warsaw, interviews were carried out with officials representing selected organisational units of the City Hall in 2010 and 2011, viz. Architecture and Spatial Planning, Business Activity and Permits, Education, Culture, Investors Service, Flat Policy, City Promotion, City Development, and Social Communication. The unit most deeply involved in the functioning of the creative sector in Warsaw was the Bureau of Culture. Indirectly involved were the Centre for Social Communication and the Investors Service Bureau. The remaining entities did not carry out any activities related to the creative sector. The official scope of responsibilities of the most active Bureau of Culture did not include activities associated with the creative sector. The majority of activities carried out by this Bureau, related to cooperation with entities from the creative sector, concerned the celebration of the 2009 Creativity and Innovation Year. Those activities were not continued in 2010. Programmes implemented by the Investors Service Bureau came within the scope of business and innovation support.

It should be pointed out that the idea of creativity does not exist in strategic documents (Development strategy for the capital city of Warsaw until 2020, Social strategy of Warsaw for the years 2009-2020), and what follows, there are no provisions concerning the desired instruments of support for the creative sector. It seems that the approach to the development of the creative sector is eclectic and cannot be converted into systemic activities. This may stem from the fact that the 
ideas of creativity and the creative sector are new and have not found the right place in the city's development policy. The measures undertaken that could be perceived as ones in support of the creative sector, are of more incidental nature and involve organising events with the participation of creative entities.

The city authorities have planned the development of a creative district in Warsaw. City Hall is considering a few areas, Praga being one of them. This area is characterised by a very strong concentration of cultural and leisure facilities. There are many activities aimed at creating an artistic image of the city. Praga is more and more often promoted among tourists. However, officially the creative district has not been created yet. "Plan for a creative district: with Praga for Praga" is being developed by the City Hall of Warsaw within the framework of the project "Creative metropolises: Public policies and instruments in support of creative industries" established under the BaltMet Network of the Baltic Cities. In 2010 the City Council prepared the document "Supporting creative industries in Praga Północ - Guidelines for the development of an action plan". Part of this programme was workshops in the course of which participants prepared recommendations. They proposed development recommendations for supporting the creative industries in the district, an integrated policy in support of creative industries, the establishment of clear responsibilities within city government at the district and city levels, support for community-building initiatives, engagement and inclusion that build up pride and the sense of ownership, and openness to partnerships between the creative sector, business, academia, government and NGOs.

In 2010 the local authorities also planned to establish a Working Group by the end of 2011 to deal with the creative sector in Warsaw. It was intended to be a unit for cooperation with City Hall bureaus and for coordination of activities associated with the operation of the sector. So far this group has not been appointed. There is only a Working Group for Small and Medium-Sized Enterprises active in the City Hall, responsible for all actions connected with the functioning of small and medium-sized enterprises, including creative ones.
In 2009 the City Hall started to support the creative sector. One of the most important forms of support for the creative sector was financial, such as concessions and tax exemptions. The local authorities also planned to include the creative sector into the range of activities of the Bureau of Culture. The City Hall co-organised a few events (e.g. Creative Mikser).The idea of creativity was written down in the Development Programme of Culture and in the programme of the Mayor of Warsaw. A portal for creative business was created. In 2010 the authorities planned to set up three new units in the city: the Centre of Business, the Centre of Innovativeness, and the Centre of Creativity, intended to play an information, advisory and supporting role for persons interested in running a business in a specific sector. Each of the planned centres is a separate project. Their establishment will be partly financed from the EU funds. At present all projects are in the investment phase.

In 2011 we made another survey in the City Hall. The idea of creativity still did not exist in strategic documents (Development strategy of the city, Promotion strategy, or Social strategy). There were no records concerning the desired instruments supporting the creative sector. The approach towards the development of the creative sector was eclectic and did not translate into a systemic and planned action. The City Hall only co-organised a few events, such as the Creative Commons Global Summit (16-18 September 2011).

The idea of creativity and the concept of the creative sector are new and do not have an appropriate place in city policy. Action taken by the local authorities is incidental in character and consists in organising events with the participation of creative entities. Cooperation among units involved in supporting the creative sector is clearly insufficient. In the absence of a separate unit (or team) responsible for supporting the creative sector, lack of cooperation can be alarming.

Another stage of the study focused on the opinions of creative companies about the support policy addressed to the creative sector in Warsaw. According to its representatives, the support given by the city authorities was minuscule or unnoticeable. None of the respondents heard about support instruments. The possibility 
of participating in a tender or competition organised by selected City Hall bureaus was perceived as an indirect form of support. It would be very important if the initiatives were large-scale and exceeded current needs of the city, serving directly the purpose of developing the creative sector and creative products, which have an impact on the city's image. However, the entrepreneurs surveyed did not regard those initiatives (competitions, tenders) as resulting from a particular interest of the city authorities in developing the creative sector or its products.

\section{Summing up}

It is difficult to trace a typical development path of the creative sector and to identify its impact on a city's development. The basic problem involves the definition of this sector. The versatility of definitions and classifications of activities carried out in the sector results in different cities offering quite unique developmental conditions. A factor that largely determines development paths of the creative sector is also the economic situation of a place and its social capital. The size of the city, its role in the national and supranational urban networks, as well as the nature of its economic development base are yet other factors influencing the situation in the creative sector. Also strategic documents, such as a development strategy of the city, its promotion strategy, cultural strategy or social strategy, cannot be underestimated here.

The study has revealed that there are many entities generating creative products in Warsaw. They are both big international firms, seats of all national media, important cultural facilities, scientific institutions and universities as well as small businesses that generate products for the needs of individual consumers. This sector has been changing dynamically, and the city's unique characteristics contribute to its development. In the opinion of the majority of representatives of the creative sector, Warsaw is attractive to this sector, and there are areas particularly interesting to specific industries. Creative entities have a tendency to concentrate in specific areas, especially in the central districts, i.e. Śródmieście and Praga Południe, as well as southern districts, i.e. Mokotów and Ursynów. These districts are also perceived by the respondents as attractive for creative investment. Other areas with good conditions for the cultural sector are peripheral districts as well as Praga and Żoliborz. The capital's competitiveness was, however, assessed negatively. It was pointed out that the city had great potential which (if used properly) could be crucial for its competitive advantage. But it was necessary for the city authorities to implement activities that supported the development of the creative sector, because now its image was rather weak.

Directions of development of the creative sector as well as the nature of this development are also a result of development policies. Those addressed to the creative sector are also aimed at counteracting social exclusion, supporting human capital and developing local communities. On the basis of our research, it seems that the Warsaw authorities notice the significance of the creative sector for the development of the city's economic base. The idea of creativity and the concept of the creative sector are new and do not have an appropriate place in city policy. Actions taken by local authorities have incidental character. Cooperation among units involved in supporting the creative sector is clearly insufficient. In the absence of an assigned unit (or team) responsible for supporting the creative sector, lack of co-operation can be alarming. A decision was taken to establish a "creative district". Plans were made to set up a Creativity Centre. The City Hall co-organised a few events addressed to creative companies. One of the most important forms of support for the development of the creative sector was financial instruments, such as concessions and tax exemptions. Entrepreneurs who generate creative products declare their readiness to participate in programmes addressed to the sector and wait for a strategy of the development of the creative sector in Warsaw. In their opinion, the City Hall has a lot of plans, but now the most important activity is to prepare a strategic document organising all actions and forms of support. Experiences of many European cities prove that the right support policy for the creative sector can contribute to an improvement in a city's attractiveness and competitiveness as well as to the development of its positive and strong image. 


\section{References}

Dudek-MańKowska S., Fuhrmann M., Grochowski M., Zegar T., 2011. Potential and conditions for the development of the creative sector in Warsaw. Miscellanea Geographica, 15: 171-186

FLORIDA R., 2005. Cities and the creative class. Routledge, New York.

GROCHOWSKI M., 2010. Sektor kreatywny w Warszawie. Potencjat $i$ warunki rozwoju (Creative sector in Warsaw. The poten- tial and conditions for development). Creative Metropoles, Warsaw.

Hong Kong Arts Development Council, 2006. Hong Kong: Culture and creativity. Hong Kong.

Stryjakiewicz T., Męczyński M., Stachowiak K., 2009. Sektor kreatywny w poznańskiej gospodarce (Creative sector in the Poznań economy). Expert's report for the Poznań City Hall. Uniwersytet im. A. Mickiewicza, Poznań. 